\title{
İSLAM VE OSMANLI CEZA HUKUKUNDA İNFAZIN ERTELENMESI
}

POSTPONEMENT OF EXECUTION IN ISLAMIC AND OTTOMAN LAW

Hakemli Makale

Melikşah AYDIN*

\begin{tabular}{|c|}
\hline INDEKILER \\
\hline cus \\
\hline \\
\hline$\ldots . .1217$ \\
\hline B. Sarhoşluk.. \\
\hline 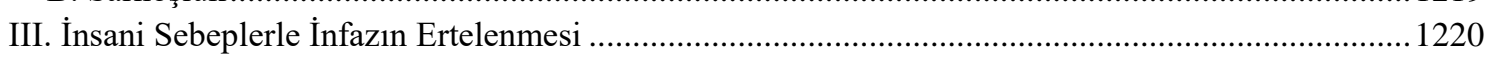 \\
\hline 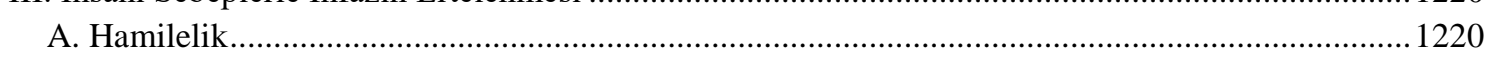 \\
\hline ...1220 \\
\hline$\ldots 1223$ \\
\hline$\ldots 1224$ \\
\hline B. Hastalık.. \\
\hline 1. Ölüm Cez \\
\hline 2. Organ Kesme Cezasinda \\
\hline 3. Celde Cezasinda... \\
\hline 4. Dayak \\
\hline$\ldots 1228$ \\
\hline ahip Olan Kimsenin Akıl Hastası, Küçük veya Gaip Olmas1 ...................1229 \\
\hline .......1230 \\
\hline IV. İnfaz Yapılacak Ortamın Uygun Olmaması Sebebiyle Erteleme ........ \\
\hline 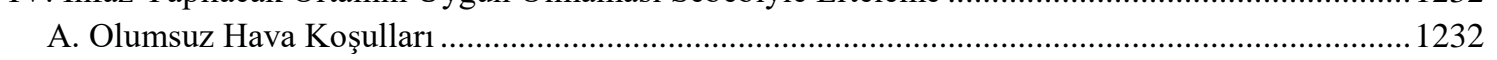 \\
\hline 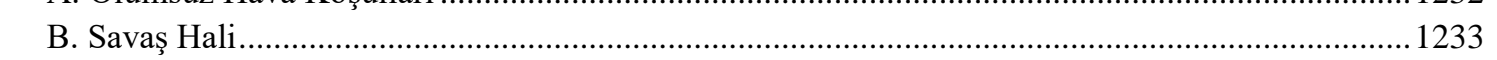 \\
\hline Farklı Sebeplerle Erteleme ... \\
\hline. .1237 \\
\hline AYNAKÇ. \\
\hline
\end{tabular}

DOI: $10.32957 /$ hacettepehdf.1037226

Makalenin Geliş Tarihi: 13.12.2021

Makalenin Kabul Tarihi: 28.12.2021

* Arş. Gör. Dr. Selçuk Üniversitesi Hukuk Fakültesi Hukuk Tarihi Anabilim Dalı Araştırma Görevlisi. E-posta: aydinmeliksah@gmail.com

ORCID: 0000-0002-4077-5025

Bu makale Hacettepe Üniversitesi Hukuk Fakültesi tarafından kabul edilmiş ulusal ve uluslararası araştırma ve yayın ilkelerine uygun bir biçimde yazılmıştır. 


\title{
ÖZ
}

İslam hukukundaki genel ilkeye göre kişilerin aldığı cezaların infazı hemen yapılmalıdır. İnfazı geciktirmeden yerine getirmek hâkime verilmiş bir görevdir. Bazı sebeplerin varlığı halinde ise infazın ertelenebileceği İslam hukukunda öngörülmüştür. Bu sebeplerin mahkûmdan kaynaklananları; mahkûmun hamileliği, hasta olması, sarhoş olması, akıl sağlı̆̆ını kaybetmesi, mağdurdan kaynaklananları; kısas hakkına sahip olan mağdurun küçük, gaip veya akıl hastası olması, mağdurun yarasının bulunması, infaz yapılacak ortam ile ilgili olanları havanın çok sıcak veya soğuk olması ve savaş halidir. Bu durumlarda verilecek bazı cezalar ertelenirken bazı cezalar ertelenemez. İnfazı ertelenen cezaların çoğunlukla bedeni cezalar olduğu görülmektedir. Ölüm cezalarının infazı, hamilelik gibi bir suçsuzun cezalandırılması veya mağdurun kısas hakkından feragat etmesiyle mahkûmun kurtarılması sonucunu doğuracaksa ertelenebilir. Had ve tazir cezaları ise hastalık, sarhoşluk, infaz yapılacak ortamın uygun olmaması, mağdurun yarasının iyileşmemesi gibi sebeplerle ertelenebilir. İnfazın ertelenmesi mağdur olan kişilerin hakları çiğnenmeden mahkûmun, mağdurun veya toplumun yararına sonuçlar doğurabilir.

Anahtar Kelimeler: İslam hukuku, Osmanlı hukuku, infaz hukuku, cezanın infazı, erteleme.

\begin{abstract}
According to the general principle in Islamic law, the execution of punishments should be done immediately. It is the duty of the judge to carry out the execution without delay. In the presence of certain reasons, it is stipulated in Islamic law that the execution may be postponed. The reasons arise from the convict are following: convict's pregnancy, illness, drunkenness and mental illness. The reasons arise from the victim are following: being young, lost or mentally ill of the victim who has retaliation right and victim's injury. The reasons pertaining about the execution environment: too hot or cold weather and warfare. In these cases some penalties can be postponed and some can't. It is seen that the sentences whose execution is postponed are mostly corporal punishments. Execution of death sentences may be postponed if it results as punish an innocent person like convict's pregnancy or liberation of the convict as victim's abandonment from his retaliation right. Had and tazir crimes may be postponed due to illness, drunkenness of the convict and unsuitable environment for execution and victim's not healed wound. Postponing the execution may have consequences for the benefit of the convict, the victim or the community without violating the rights of the victims.
\end{abstract}

Key Words: Islamic law, Ottoman law, execution law, execution of punishment, postponement. 
"Ya Eba Musa! Huzurunda bir hususta terafu'-i hasmeyn vaki' oldukda, tarafeynin kelamlarını ala-vechi'l-îkan fehm ü iz'an edip hak zahir ve mütebeyyin olduktan sonra hükm-i şer'i icra, tenfiz ve imza lazime-i zimmettir. Zira elsine$i$ hukkamdan sudur eden kelam-ı hak, hilye-i nüfuzdan atıl oldukda, lafz-ı bî-mana gibi faideden hali emr-i bi-tail olduğu mukarrerdir." Hz. Ömer'in Ebu Musa el-Eş'ari'ye mektubundan.

\section{GíRiş}

Osmanlı ceza hukukunda infazın ertelenmesi isimli bu çalışmada bir suç işlemesi sebebiyle yapılan yargılaması sonucu hakkında ceza verilen hükümlünün cezasının infazının hangi durumlarda ertelenebileceği temelde İslam hukuku kaideleri ve Osmanlı uygulaması ile açıklanacaktır. İslam hukukunda temel fikıh kitapları, konu ile ilgili kitap ve makaleler, Osmanlı uygulamasında ise fetva kitapları, kadı sicilleri ve diğer arşiv belgeleri esas alınmıştır.

Cezalandırmanın genel kabul gören görüşe göre iki temel amacı vardır: Bir daha suç işlenmesini önlemek için caydırıcılık ve mahkûmun 1slahı. Hâkimin verdiği cezanın infazının hemen yapılması ve geciktirilmemesi esas olmakla beraber bazı istisnai durumlarda cezalandırmanın bu iki amacına ulaşılabilmesi için infazın ertelenmesi daha uygun olur. Ayrıca cezaların bireyselliği, infazın insaniliği ilkeleri de infazın ertelenmesinde esas alınan ilkelerdendir. Çünkü ceza sonucunda suçsuz olan birisi de cezalandırılacaksa veya infaz sonrasında normal bir mahkûmun çekeceği cezaya göre mahkûmun içinde bulunduğu koşul sebebiyle daha çok acı çekecekse infazın ertelenmesi yoluna gidilmelidir.

Batı hukukuna girişi oldukça geç olan infazın ertelenmesi kurumuna İslam hukukunda bizzat Hz. Peygamber'in uygulamasında rastlanmaktadır. İslam hukuku infaz sebeplerini bazı durumlarda hâkimin takdirine bırakırken bazı sebeplerin varlığı halinde ise infazın kesin olarak ertelenmesini emretmiştir. 


\section{I. İnfaz Sözcüğü ve Genel Olarak İnfazın Ertelenmesi Kavramları}

İnfaz sözcügü kelime anlamı olarak "içine işlemek, delip geçmek” anlamındaki “nefaz" kökünden gelmekle beraber ${ }^{1}$ bir emrin veya hükmün gereğinin yerine getirilmesi, yapılması anlamındadır. ${ }^{2}$ Ceza hukukunda infaz, kesinleşmiş hükmün gereğini yerine getirmek anlamındadır. ${ }^{3}$ İnfaz hukuku ise "ceza mahkemelerince verilen ceza ve güvenlik tedbirlerine ilişkin kesinleşmiş kararların yerine getirilmesine ilişkin esasları gösteren bağımsız bir hukuk dalıdır. ",

Mahkeme veya hâkim tarafından yapılmış olan yargılama sonunda verilen cezanın infazının yapılması toplum güvenliğinin sağlanması ve adaletin tesisi için önemlidir. Bazı durumlarda ise infazın ertelenmesi adalete daha uygun düşebilir. Bu durumlarda infazın yapılması ile beklenen fayda gerçekleşmeyeceğinden erteleme yoluna gidilmektedir. İnfazın hemen icrasının mahkûm veya mahkûmun aile efradı bakımından kötü sonuçlar doğurabileceği bu istisnai durumlarda infazın ertelenmesi hemen uygulanmasına göre daha adil olacaktır. ${ }^{5}$

İnfazın ertelenmesi ile ilgili Kur’an-1 Kerim’de Nahl suresinde “Ĕ̆er Allah insanları haksızlıkları yüzünden hemen cezalandıracak olsaydı yeryüzünde hiçbir canlı bırakmazdl. Fakat onlara belirlenmiş bir sürenin sonuna kadar mühlet tanıyor. Ama süreleri dolduğunda onu bir an bile ne erteleyebilirler ne de öne alabilirler." (Nahl, 16/61) ve Yunus suresinde ise "Ĕ̆ger insanlar iyi olanı çarçabuk istedikleri gibi kötü olanı da Allah onlar için hemen gerçekleştirseydi derhal sonları gelirdi. Bize

1 ÖZEN, Şükrü, “İnfaz”, Türk Diyanet Vakfı İslam Ansiklopedisi (DİA), C.22, İstanbul, 2000, s.290.

2 YILMAZ, Ejder, Hukuk Sözlüğ̈̈, 9. Baskı, Yetkin Yayınları, Ankara, 2005, s.560; DEVELLİOĞLU, Ferit, Osmanlıca-Türkçe Ansiklopedik Lügat, Aydın Yayınları, Ankara, 2013, s.502; ÖZGÜR, Mustafa, İslam İnfaz Hukuku, Cinius Yayınları, İstanbul, 2020, s.48.

3 Türk Hukuk Lügati, 3. Baskı, Başbakanlık Basımevi, Ankara, 1991, s.52; SAĞLAM, M. Yılmaz, "İnfaz ve İfaz Hukuku Kavramları Üzerine Bir Inceleme", TBB Dergisi, 1995/4, s.580; ÖZEN, 2000, s.290; ÖZGENÇ, İzzet / ŞAHIN, Cumhur, İnfaz Hukuku, 3. Baskı, Seçkin Yayınları, Ankara, 2020, s.15.

4 ÖZBEK, Veli Özer, İnfaz Hukuku, 13. Baskı, Seçkin Yayınları, Ankara, 2021, s.29. Bir başka tanıma göre ise infaz hukuku; "ceza hukuku yaptırımlarının uygulanması sürecine ilişkin kurallar bütünüdür." ÖZGENÇ/ŞAHIN, 2020, s.15.

5 MEZURİ, Waadi Süleyman, "Cezanın Ertelenmesi: Beşeri Kanun ve İslam Hukuku Arasında Bir Mukayese", (çev. O. Güman), İslam Ceza Hukuku Uluslararası Sempozyumu Tebliğler Kitabı, Lale Yayınc1lık, İstanbul, 2017, Cilt 2, s.863. 
kavuşacaklarına inanmayanlarl, azgınlıkları içinde bocalayıp durmak üzere kendi hallerine bırakırız" (Yunus, 10/11) denilmiştir. Bu ayetlerden hak edilmiş olan bir cezanın infazının hemen verilmediği ve ertelendiği anlaşılmaktadır. ${ }^{6}$

İnfazın ertelenmesi genel olarak infaz ehliyetini kaldıran sebeplerle, mahkûmda ortaya çıkan insani sebeplerle, infaz yapılacak ortamın uygun olmaması sebebiyle veya başka sebeplerle ortaya çıkabilir.

\section{II. İnfaz Ehliyetini Kaldıran Sebeplerle İnfazın Ertelenmesi}

Cezalandırmanın temel amaçlarından biri mahkûmun ıslahıdır. Mahkûmun ıslah olabilmesi için infaz ehliyetinin bulunması gerekir. İnfaz ehliyeti ise mahkûmun infazın başından sonuna kadar akıl ve beden sağlığının bulunması olarak anlaşılabilir. Yani mahkûm cezayı üstlenebilmeli ve ondan istifade edebilecek konumda olmalıdır. İnfaz ehliyeti mahkûmun yaşı, durumu ve hayat tarzına göre değişir. Bu ehliyet mahkûmun akıl ve beden sağlığına sahip olması ayrıca kendisine neden ceza verildiğini anlayabilmesi ve 1slah olma kapasitesine de sahip olması ile ilgilidir. ${ }^{7}$

\section{A. Akıl Hastalı̆̆ı}

İnfazın ertelenmesi sebeplerinden birincisi mahkûmda ortaya çıkan akıl hastalığıdır. İnfaz anında mahkûmun akli melekelerinin yerinde olması gerekir. Akı1 sağlığına sahip olmayan kimselerin ceza ehliyetinin bulunmadığı bilinmekle beraber suç teşkil eden fiili işleyen kişinin suçu işlediği sırada akıl sağlığı bulunmuyorsa zaten kendisine bir ceza verilemeyecektir. Ancak fiili işlediği sırada tam ehliyetli olup daha sonra cezanın infazından önce akıl hastası olan kişinin infazı etkilenebilir. Bu konuda mezhepler arasında görüş ayrılıkları vardır.

Şafii ve Hanbelilere göre suçun hangi şekilde ispat edildiği önemlidir. Eğer failin ikrarı ile suç ispatlanmışsa infaz ertelenir. Çünkü ikrardan her zaman dönmek mümkün olduğu için failin infazdan önce ikrarından dönebileceği ihtimali sebebiyle infazı

6 Kur'an Yolu Türkçe Meal ve Tefsir, DİB Yayınları, Ankara, 2012, C.III, s.88, 412; AVCI, Mustafa, Osmanlı Ceza Hukuku Genel Hükümler (I), 3. Baskı, Adalet Yayınevi, Ankara, 2018, s.444.

7 MEZURİ, 2017, s.863. 
ertelemek gerekir. Ancak suç ikrar dışındaki bir delil ile ispatlanmışsa infazın ertelenmesine gerek yoktur. ${ }^{8}$ Cezalandırmanın iki amacından birisi olan özel önlemenin yani mahkûmun 1slahının bu açıdan sağlanması uzak bir ihtimal olmasına rağmen genel önleme yani toplumun menfaati sebebiyle suçun tekrarının önlenmesi sağlanabileceği için infazın ertelenmesi toplum menfaatinin aleyhine olur. ${ }^{9}$ Kısas suçları açısından ise Şafii ve Hanbeliler suçun ne şekilde ispatlandığına bakmaz ve suçun ispatından sonra ortaya çıkan akıl hastalığının infazı ertelemeyeceğini söylerler. ${ }^{10}$

Hanefilere göre akıl hastalığı bulunan kişiye had cezası verilemez. Ceza infaz edilmeden mahkûmda ortaya çıkan akıl hastalığı infazın ertelenmesi sebebidir. ${ }^{11}$ Kısas cezası açısından ise Hanefilere göre kısasa hükmedildikten sonra hâkim cezanın infazı için mahkûmu kısas hakkı sahiplerine teslim etmeden mahkûm akıl hastalığına tutulursa infaz ertelenir. Akıl hastalığının iyileşmesinin uzun bir süre alacağı belli olursa kısas cezası istihsanen diyete dönüştürülür. ${ }^{12}$ Ancak hâkim, mahkûmu kısas hakkı sahiplerine teslim ettikten sonra mahkûm akıl hastalığına tutulursa infaz ertelenmez, teslimden itibaren infaz başlamış sayılır. ${ }^{13}$

8 ŞİRBİNi, Şemseddin Muhammed b. Ahmed el-Hatîb, Muğni’l- Muhtac, (çev. S. Duman), Mirac Yayınları, İstanbul, 2017, C.16, s.252; EBU ZEHRA, Muhammed, el-Cerime ve'l-Ukube fi Fıkhi'lİslami, (İslam Hukukunda Suç ve Ceza), (çev. İ. Tüfekçi), İstanbul, 1994, C.1, No:470; MEZURİ, 2017, s.877. Nasıl ki davada şahit olarak dinlenen kişiler şahitliklerini tamamladıktan sonra hüküm verilmeden önce akıl hastası olurlarsa bunun hükme bir etkisi yoksa bu durumun da infaza bir etkisi olmaz.

9 UDEH, Abdülkadir, Mukayeseli İslam Ceza Hukuku, (çev. A. Şafak), 2.Baskı, Kayıhan Yayınları, İstanbul, 2012, C.1, s.609; AVCI, Mustafa, "Osmanlı İnfaz Hukukundaki Gelişmelere Genel Bir Baklş”, SÜHFD, Sy:3-4, 2004, s.147; ÖZGÜR, 2020, s.119.

10 ZUHAYLİ, Vehbe, İslam Fıkhı Ansiklopedisi, (ilmi müşavir M. Emin Saraç, çev. Heyet), Risale Yayınları, İstanbul, 1994, C.8, s.65; ÖZGÜR, 2020, s.119.

11 EBU ZEHRA, 1994, C.1, No:470; CIN, Halil / AKGÜNDÜZ, Ahmet, Türk Hukuk Tarihi, OSAV Yayınları, İstanbul, 2017, s.301; YURTSEVEN, Yılmaz, Klasik Dönem Osmanlı Ceza Hukukunda Tazir Suç ve Cezaları, Selçuk Üniversitesi Sosyal Bilimler Enstitüsü, Basılmamış Yüksek Lisans Tezi, Konya, 2001, s.25; AVCI, 2004, s.138.

12 FETAVA-YI HíNDIYYYE, Fetava-yı Alemgiriyye, (çev. M. Efe), Huzur Yayınları, İstanbul, 2004, C.12, s.465; İBN ABIDİN, Muhammed Emin b. Ömer, Reddü'l-Muhtar ale'd-Dürri'l-Muhtar, (çev. A. Davudoğlu ve M. Savaş), Şamil Yayınları, İstanbul, 1983, C.16, s.249. İstihsanen bu cezanın verilmesinin amacı şudur: Mahkûmun mademki bedeni olarak cezalandırılması mümkün olmuyor mali olarak kendisine tazminat ödettirilsin ki suçun kul hakkı boyutu bir nebze olsun giderilsin. EBU ZEHRA, 1994, C.1, No:470; MEZURİ, 2017, s.877.

13 FETAVA-YI HINNDIYYYE, 2004, C.12, s.465; UDEH, 2012, C.1, s.609; ÖZGÜR, 2020, s.120. 
Maliki mezhebinin görüşü ise genel olarak Hanefi mezhebi ile örtüşse de mezhep içindeki bir görüşe göre kısas cezasının infazında kısas hakkı sahibine söz hakkı tanınır, mahkûmun kendisine tesliminden sonra isterse kısas eder, istemezse etmez. ${ }^{14}$ Bir diğer görüşe göre ise mahkûmun akıl sağlığını kazanmasına kadar infaz ertelenir. İyileşme umudu yoksa ceza diyet cezasına çevrilir. ${ }^{15}$ Burada kısas cezasının tazir cezasına dönüşerek tazminat ödettirilmesi söz konusu olur.

Mezheplerin görüş birliğinde olduğu durum ise tazir cezalarının infazı konusundadır. Buna göre mahkûmun infazdan önce akıl hastalığına tutulması infazın ertelenmesini gerektirir. Tazir cezasının ıslah amacı burada gerçekleşmeyeceği için bu görüş benimsenmiştir. ${ }^{16}$

\section{B. Sarhoşluk}

Cezalandırmanın temel amaçlarından birisi daha önce de belirtildiği gibi mahkûmun ıslahıdır. Kendisine verilecek olan cezayı hissedemeyecek derecede sarhoş olan mahkûmun infazı ertelenmelidir ki kendisinin 1slahı sağlanabilsin ve böyle bir suçu tekrar işlemesin. Bu konuda dört mezhep de aynı görüştedir. ${ }^{17}$

Bir rivayete göre taşıdığı matarada içki bulunan sarhoş bir kimse halifeliği devrinde Hz. Ömer'e getirilmiştir. Hz. Ömer de şürb (içki içme) suçunu işlemiş olan bu kimseyi ayılıncaya kadar hapsettirmiş, suçun karşılığı olan celde cezasının infazını ertelemiştir. ${ }^{18}$

14 UDEH, 2012, C.1, s.609; ZUHAYLİ, 1994, C.8, s.66; MEZURİ, 2017, s.877.

15 EBU ZEHRA, 1994, C.1, No:470; ÖZGÜR, 2020, s.120.

16 EBU ZEHRA, 1994, C.1, No:471. CİN/AKGÜNDÜZ, 2017, s.301.

17 EBU YUSUF, Yakub b. İbrahim, Kitabu'l-Harac 2. Baskı, Özek Yayınları, (çev. A. Özek), İstanbul, 1973, s.260-261; İBN ABİDİN, 1983, C.8, s.235; UDEH, 2012, C.1, s.762; ÖZEN, 2000, s.290-291; FENDOĞLU, Hasan Tahsin, Türk Hukuk Tarihi, Filiz Kitabevi, İstanbul, 2000; AVCI, 2004, s.90, 109; ÖZGÜR, 2020, s.126. Şirbini’ye göre bunun sebeplerinden biri de kişinin ne şekilde sarhoş olduğunu bilinmemesidir. Yanlışlıkla (taksirle) veya ikrah altında sarhoş olan kişi cezalandırılamayacağı için şüphe vardır. Şüphe ile de hadler düşer. ŞİRBİNİ, 2017, C.16, s.455-456; İBN ABİDIN, 1983, C.8, s.232.

18 SERAHSİ, Ebu Bekir Muhammed b. Ahmed, Mebsût, ed. Mustafa Cevat Akşit, Gümüşev Yayıncılık, İstanbul, 2008, C.24, No: 11; AVCI, (I), s.445; ACAR, Betül, Fıkıh Teori ve Uygulamasında Yargılama ve İnfazın Aleniliği, İstanbul 29 Mayıs Üniversitesi Sosyal Bilimler Enstitüsü, Yayımlanmamış Doktora Tezi, İstanbul, 2020, s.52. 
Eğer mahkûm sarhoş olmasına rağmen yine de cezası infaz edilirse Hanefilerin tercih edilen görüşüne göre cezalandırmanın amacı gerçekleşmediği için mahkûm ayıldıktan sonra tekrar cezalandırılmalıdır. ${ }^{19}$ Hanefilerin diğer bir görüşünde ise infazın mahkûmda acıya sebep olmaması söz konusu olmasına rağmen infaz gerçekleştirildiği için tekrar ikinci bir infaza gerek yoktur. Şafiiler de bu görüştedir. ${ }^{20}$

Bozok Kanunu'nda “...ve süci içse ayıldıktan sonra seksen ăgaç uralar vurmazlarsa seksen akçe alına... "21 denilerek içki içme suçunun cezasının infazının fail ayıldıktan sonra verilmesi gerektiği belirtilmiştir. Aynı husus Alaüddevle Bey Kanunu'nda da düzenlenmiştir. ${ }^{22}$

\section{III. İnsani Sebeplerle İnfazın Ertelenmesi}

İnsani sebeplerle infazın ertelenmesi mahkûmda bulunan hamilelik ve hastalık, kısas isteme hakkına sahip olan kimsenin akı1 hastası, küçük veya gaip olması, mağdur açısından ise mağdurun yarasının bulunması ve iyileşmesine kadar beklenmesi hallerinde söz konusu olur.

\section{A. Hamilelik}

Mahkûmun hamile olması infazın ertelenmesi sebeplerindendir. Mahkûmun aldığı cezalara göre değişen şekillerde erteleme söz konusu olabilir.

\section{Recm Cezasında}

Hamilelik sebebiyle infazın ertelenmesi bizzat Hz. Peygamber'in uygulamalarında görülmektedir. Rivayet edildiğine göre bir gün Gâmidli bir kadın Hz. Peygamber'e gelerek zina suçunu işlediğini ve bundan dolayı kendisini temizlemesini istiyor. Hz. Peygamber de “Vah sana! Dön de Allah 'tan mağfiret dile, ona tövbe et! ” buyurmuşlardır.

19 İBN ABİDì, 1983, C.8, s.236.

20 ŞİRBIINİ, 2017, C.16, s.458; ÖZGÜR, 2020, s. 126.

21 BARKAN, Ömer Lütfi, XV ve XVI incı Asırlarda Osmanlı İmparatorluğunda Zirai Ekonominin Hukuki ve Mali Esasları Birinci Cilt Kanunlar, İstanbul, 1943, s.127; AKGÜNDÜZ, Ahmed, Osmanlı Kanunnameleri ve Hukuki Tahlilleri, C.6, Fey Vakfı Yayınları, İstanbul, 1993, s.230.

22 BARKAN, 1943, s.123; AKGÜNDÜZ, Ahmed, Osmanlı Kanunnameleri ve Hukuki Tahlilleri, C.7, Fey Vakfı Yayınları, İstanbul, 1994, s.159. 
Bunun üzerine kadın 1srarla tekrar gelip "Ya Resulallah! Görüyorum ki beni de Maiz gibi geri çeviriyorsun. Vallahi ben zinadan dolayı gebeyim.” demiştir. Bunun üzerine Hz. Peygamber kadına çocuğu doğurmasını söylemiştir. Bebeği doğurduktan sonra tekrar Hz. Peygamber'in huzuruna gelen kadına Efendimiz “Çocuğu sütten ayırıncaya kadar emzir! ” buyurmuştur. Kadın çocuğu sütten kesildikten sonra ve çocuğun elinde bir ekmek parçası bulunmaktayken tekrar gelmiş "Işste çocuğumu sütten kestim, yemek yemeye de başladı" demiştir. Bunun üzerine Hz. Peygamber çocuğun bakımını Ensar'dan bir sahabeye vermiş ve kadının da recmedilmesini emretmiştir. Bir çukur kazılıp kadın da göğsüne kadar bu çukura konulduktan sonra recmedilmiştir. ${ }^{23}$ Hatta recm sırasında Halid b. Velid'in üzerine kadının kanı sıçramış o da kötü bir söz söyleyince Hz. Peygamber "Yavaş ol ya Halid! Nefsim yed-i kudretinde olan Allah'a yemin ederim! Bu kadın öyle bir tevbe etti ki, onu bir baççı yapsaydı mutlaka mağfiret olunurdu!” buyurmuşlardır. Daha sonra kadının cenaze namazını Hz. Peygamber kıldırmıştır. Hz. Ömer, "Zinadan dolayı recmedilen bu kadının cenaze namazını mı kıldıracaksın ya Resulallah?” deyince Hz. Peygamber, "Gerçekten o öyle bir tevbe etti ki, bu tevbe Medinelilerden yetmiş kişi arasında taksim edilse onlara yeterdi. Sen Allah için canını vermekten daha faziletli bir tevbe gördün mü?" buyurmuştur. ${ }^{24}$

$\mathrm{Bu}$ hadis infazın ertelenmesindeki temel sebeplerden bazılarını ortaya çıkarmıştır. Hadisi tahlil edecek olursak bir kadın zina suçunu yargılama makamı olan Hz. Peygamber'e gelerek itiraf etmiştir. İkrar, suçun kanıtlanması için gereken temel delillerden olduğu için bu kadının cezalandırılması gerekecektir. Dul olan bu kadının zina suçuna recm cezası gerekir. Recm cezası ile mahkûmun taşlanarak öldürülmesidir. Ancak hamile olan bu kadın taşlanarak öldürülürse karnındaki bebeği de ölecek veya zarar görecektir. Hz. Peygamber kadının suçunun cezasını karnındaki suçsuz ceninin de çekmemesi için bebeğin doğumuna kadar kadına süre tanımıştır. Kadın doğumdan hemen sonra recmedilse bebek en temel ihtiyacı olan annesinden ve anne sütünden mahrum kalacaktır. Bebeklerin ilk doğduklarından itibaren annelerine ve anne sütüne ihtiyaç duydukları ve bebeğin sağlıklı olması için özellikle anne sütünün gerekliliği modern tıbbi

\footnotetext{
23 Buhari, Hudud, 30-31; İbn Mace, Hudud, 3; EBU YUSUF, 1973, s.257, 259.

24 Müslim, Hudud, Hadis No: 1695-1696.
} 
araştırmalarda da kanıtlanmıştır. İşte bu sebeple Hz. Peygamber bebeğin sağlıklı bir şekilde anne sütünü almasını istemiştir. Daha sonra bebek anne sütünden kesildiğinde de bebeğin bakımını üstlenecek bir sahabe ortaya çıktıktan sonra kadının cezası infaz edilmiştir. Burada infazın temel özelliklerinden olan infazın şahsiliği ilkesine riayet edildiğini ve suçlu bir kimsenin suçundan dolayı suçsuz olan başkalarının zarara uğramamasına dikkat edildiğini görmekteyiz. ${ }^{25} \mathrm{Bu}$ durum Kur'an'da da belirtilmiştir: “Herkesin yaptı̆̆ının sonucu kendisine aittir. Hiçbir suçlu başkasının suçunu yüklenmez." (En'am, 6/164)

Hz. Ömer, halifeliği devrinde zina ettiği ispatlanan hamile bir kadının recmedilmesine hükmetmişti. Bu karar üzerine Muaz b. Cebel "Senin onu bu şekilde öldürmeye yetkin vardır. Ama karnındaki bebeği öldürmeye cezalandırmaya hakkın yok" demiştir. Bu cevaba sevinen Hz. Ömer ise "Analar senin gibisini doğuramaz, Muaz!" demiş ve hamile kadının recmedilmesini ertelemişti. ${ }^{26} \mathrm{~Hz}$. Ali ise halifeliği devrinde zina ettiği ispatlanan Şüraha isimli bir kadının recmedilmesine hükmetmiş, kadının hamile olduğu anlaş1lınca doğuma kadar onu hapsetmiş ve doğumdan sonra infazı gerçekleştirmiştir. $^{27}$

Zina suçundan dolayı recm cezasına çarptırılan hamile kadın bebeğini doğurduktan sonra bebeğe bakacak ve emzirecek olan başka kişiler bulunursa bebeğin sütten kesilmesi beklenmez, infaz doğumdan hemen sonra gerçekleştirilir. ${ }^{28}$

25 BİLMEN, Ömer Nasuhi, Hukuk-ı İslâmiyye ve Istılahat-ı Fıkhiyye Kamusu, Bilmen Yayınevi, İstanbul, 1970, C.3, s.224; EBU ZEHRA, 1994, C.2, No:232; KÖROĞLU, Mehmet, İslam Ceza Hukukunda Ölüm Cezası ve İnfaz Usulleri, Atatürk Üniversitesi Sosyal Bilimler Enstitüsü, Yayımlanmamış Doktora Tezi, Erzurum, 2004, s.81.

26 Buhari, Talak, 20,33,53; İbn Mace, Hudud, 3; ABDURREZZAK, Ebû Bekr Abdurrezzâk b. Hemmâm es-Ṡan 'ânî (ö.211/827), el-Musannef (nşr. Ḩabîburraḥmân el-Azamî), I-XI, el-Mektebu'l-İ̀lâmî, Beyrut 1403H, VII, 354; EBU ZEHRA, 1994, C.2, No:232.

27 MUTTAKÎ EL-HINNDÎ, Alâeddin Alî b. Hiisâmeddîn, Kenzu'l-'Ummâl (nşr. Bekrî Ḥayyânî), Müessesetü'r-Risâle, 1401/1981, V, 421-422, No:13491; EBU ZEHRA, 1994, C.2, No:232; AVCI, (I), s.456; ACAR, 2020, s.144-145.

28 İBN ABİDIN, 1983, C.8, s.190; HALEBİ, İbrahim, İzahlı Mülteka el-Ebhur Tercümesi, (çev. M. Uysal), Dizerkonca Matbaas1, İstanbul, 1968, C.2, s.274; EBU ZEHRA, 1994, C.2, No:232. 
"Zeyd'in zevcesi Hind, 'benim hamlim Zeyd'den değildir; Amr bana zina eyledi ondandır' dese Hind'e ne lâzım olur? Cevâb: Imameyn katında recm lâzım olur, ba'de'lvaz' (doğumdan sonra) Amr inkâr ederse dahî itibar olunmaz."29

"Hamile olan Hind-i muhsananın zina ettiği vech-i şer'i üzere sabit olup recmi lazım olduktan sonra Hind, vaz'-ı hamledip doğurduğu veledin ahar mürebbiyesi olsa Hind'in recmi bir ya iki sene tehir olunmak lazım olur mu? Cevab: Olmaz. ”30

Zina ettiği tanık ifadeleri ile kesinleşen kadın, hamile olduğunu iddia ederse sadece bu söze dayanılarak infaz ertelenemez, bu konuda bilirkişilerin kadının hamileliğini doğrulaması gerekir. ${ }^{31}$ Osmanlı kadı sicillerine yansıyan bir örnekte tazir cezası alan bir kadının hamile olmadı̆̆ını başka bir kadın söylemiş, aksi çıkarsa sonucuna katlanacağını belirtmiştir. "Vech-i tahrîr-i hurûf budur ki Meclis-i şer'a Hesnâ bt. Abdullah, 'Aynî bt. Halil gebe değildir ĕger gebe ise ta'zîr olmadan vaz'-ı haml ederse ben mütekeffile oldum garâmetini ben çekerim' diye gıbbe't-taleb kayd-ı sicil olundu. 25 Cemâziyelevvel 971."32

\section{2. Ölüm Cezasında}

Kısasen ölüm cezasına çarptırılan bir kadın hamile ise çocuğunu doğuruncaya kadar beklenir, bebeği emzirecek bir sütanne bulunursa kısas cezası infaz edilebilir. Bulunamazsa kadın bebeğini iki sene boyunca emzirir ve bu süre sonunda çocuk sütten kesildikten sonra kısas cezası infaz edilir. ${ }^{33}$ İslam hukukuna göre irtidat eden bir kadın,

29 AKGÜNDÜZ, Ahmed, Şeyhülislam Ebussuud Efendi Fetvaları (Fetava-yı Ebussuud Efendi), OSAV, İstanbul, 2018, s.260.

30 FETAVA-YI ALİ EFENDí, Açılkamalı Osmanlı Fetvaları, haz. H. Necati Demirtaş, Kubbealtı Neşriyat, İstanbul, 2014, C.1, s.240.

31 SERAHSI, 2008, C.9, No:73; FETAVA-YI HINDIYYYE, 2004, C.4, s.18; İBN ABİDİN, 1983, C.8, s.188; BILLMEN, 1970, C.3, s.223; GÖKCEN, Ahmet, Tanzimat Dönemi Osmanlı Ceza Kanunları ve Bu Kanunlardaki Ceza Müeyyideleri, İstanbul, 1989, s.79. Şafiilerde genel olarak kabul edilen görüşe göre ise kadının hamile olduğuna yönelik beyanı esas alınır. ŞíRBíNï, 2017, C.15, s.209-210; UDEH, 2012, C.1, s.763.

32 Üsküdar Mahkemesi 26 Numaralı Sicil (H. 970-971 / M. 1562-1563) cilt: 7, sayfa: 296 Hüküm no: 615.

33 ŞİRBİNİ, 2017, C.15, s.206; FETAVA-YI HİNDIYYY, 2004, C.4, s.18; BİLMEN, 1970, C.3, s.94; UDEH, 2012, C.1, s.763; ZUHAYLİ, 1994, C.8, s.130. 
bu suçu işledikten sonra birisiyle zina edip hamile kalırsa doğum yapıncaya kadar ölüm cezas1 ertelenir. ${ }^{34}$

Mi’yar-1 Adalet’teki bir hükme göre “kısasıyla hükmolunan kadının hamile olduğu zahir olursa o halde icra-yı kısas vaz'ı haml edinceye değin tehir olunur. Vaz'ı hamlden mukaddem kısasin icrası caiz olmaz. "35

1858 tarihli Osmanlı Ceza Kanunu m.18'e göre: “İdam cezasina müstehak olan karı hamile olduğunu lede'l-ifade hamli tahakkuk ve kesb-i sübût eylediği takdirde cezası vaz'-l haml ettikten sonra icra olunur.” Burada ölüm cezasının infazı için bebeğin doğumunun beklendiğini, bebeğin sütten kesilme zamanına kadar beklenmediğini görürüz. Bu durum eğer bebeğe bakacak kimse bulunursa infazın doğumdan sonra yapılacağı ile ilgili hükme yöneliktir. Osmanlı uygulamasında da bebek doğduktan sonra akrabasından birisine, akrabası yoksa devlet yetkililerine verilip bakımı üstlenmekteydi. ${ }^{36}$

\section{El Kesme, Celde ve Tazir Cezasında}

F1kıh âlimleri Hz. Peygamber'in recm cezasındaki uygulamasını esas alarak hamile kadına uygulanacak el kesme ve celde cezalarının da doğum gerçekleşinceye kadar ertelenmesi gerektiği görüşündedirler. Çünkü hamile kadının elinin kesilmesi veya kendisine celde uygulanmasının cenine zarar vermesi veya ölümüne sebep olması ihtimali

34 BİLMEN, 1970, C.4, s.10; MEZURİ, 2017, s.871. İmam Malik’e göre irtidat suçunu işleyen kadının hamile olup olmadığının tespiti için bir adet görünceye kadar ölüm cezası ertelenir. BİLMEN, 1970, C.4, s.9; AVCI, (I), s.444. İrtidat suçunu işleyip dinden çıkan kadına, Hanefiler kural olarak ölüm cezası verilemeyeceğini savunurken diğer mezhepler kadına da ölüm cezası verilebileceği görüşündedirler. BİLMEN, 1970, C.4, s.10-11; İNCE, İrfan, "Ridde”, DİA, C.35, İstanbul, 2008, s.89.

35 AVCI, Mustafa / KARADAĞ, M. Mansur, İslam Hukukunda Kişilere Karşı Suçlar (Mi’yar-ı Adalet Şerhi), Adalet Yayınevi, Ankara, 2021, s.133.

36 AHMED ZIYYA, Mufassal Ameli ve Nazari Kanun-ı Ceza Teferruatı Şerhi, İstanbul, 1338, s.61; SAMİ, Mirat-ı Kanun-ı Ceza (Kanun-ı Ceza Şerhi), 2.Baskı, Dersaadet, 1324, s.47; GÖKCEN, 1989, s.38. Ceza kanunu şarihlerine göre göre hamile kadınlar kendilerini gereği gibi savunamayacaklarından yargılamaları bile ertelenerek doğumdan sonraya bırakılmalıdır. AHMED ZIYYA, 1338, s.61; SAMİ, 1324, s.47. 
vardır. ${ }^{37} \mathrm{~Hz}$. Ömer de zina suçunu işleyip hamile kalan bekâr bir kadına celde cezası vermiş, infazı ise doğumdan sonraya ertelemiştir. ${ }^{38}$

Osmanlı uygulamasında zina amacıyla başkalarını evine alan kadına tazir cezası verilmiş, kadın hamile olduğu için cezanın infazı doğuma kadar ertelenmiştir. ${ }^{39}$ Ebussuud Efendi'nin bir fetvasında da "Hind-i hamile habs ve tazir lazım oldukda hakim vaz'-ı haml etmeden tazir ve habs etmeğe kadir olmaz; mahvef ise habs dahi olunmayıp kefile verilir. ${ }^{, 40}$ denilerek tazir ve hapis cezası alan hamile kadına doğum yapmadan tazir cezası verilmeyeceği ve hapsedilmeyip kefaletle serbest bırakılacağı belirtilmiştir.

Hamile olduğu için kendisine verilmiş olan cezanın infazı ertelenmiş olan kadın, infaz edilinceye kadar eğer suçu kendi ikrarı ile sabit olmuşsa bırakılır, fakat suçu başka bir delille sabit olmuşsa hapsedilir. İkrardan dönme infaz gerçekleştirilinceye kadar her zaman yapılabildiği için bu şekildedir. ${ }^{41}$

\section{B. Hastalık}

Mahkûmun suçu işlerken sahip olduğu ve infaz anında devam eden veya suçu işlerken kendisinde olmayıp infaz zamanında ortaya çıkan hastalığının bulunması infazın ertelenmesi sebeplerinden biridir.

\section{1. Ölüm Cezasında}

Mahkûmun hastalığının infaz edilecek olan ölüm cezasına bir etkisi bulunmamaktadır. Çünkü mahkûm her halde ölecektir. Dolayısıyla hasta olmasının ölüm cezasının infazını ertelemesinde bir etkisi yoktur. Hastalık nedeniyle mahkûmun ölüm

37 SERAHSI, 2008, C.9, No:73; ŞİRBİNI, 2017, C.15, s.206; HALEBİ, 1968, C.2, s.274; FETAVA-YI HINDIYYE, 2004, C.4, s.18; İBN ABİDIN, 1983, C.8, s.189; BEHNESİ, Ahmed Fethi, el-Ukube fi fıkhi'l-İslami, Dirase Fikhiyye Müteharrira, 2. Baskı, Kahire, 1961, s.217; MEZURİ, 2017, s.871.

38 ACAR, 2020, s.203.

39 'fiil-i şeni' kasdiyla evine alıp cem eylediği... hamile olmakla hakkında tazir cezast ikamesi vaz'l hamline tevkif(tehir) olunduğu..." TEKİN, Yaşar, Şer'iye Sicilleri Işı̆̆ında Osmanlı Devletinde Tazir Suç ve Cezaları, Marmara Üniversitesi Sosyal Bilimler Enstitüsü, Yayımlanmamış Yüksek Lisans Tezi, İstanbul, 1995, s.103-104, akt. AVCI, 2004, s.108.

40 AKGÜNDÜZ, 2018, s.261.

41 FETAVA-YI HİNDIYYY, 2004, C.4, s.18; İBN ABİDİ, 1983, C.8, s.187; AVCI, 2004, s.108. 
cezasının infazının ertelenmesi adaletin tecellisinin geciktirilmesine sebep olur. Bu durum İslam hukuku açısından ölüm cezası ve recm cezasında söz konusu olur. ${ }^{42}$

\section{Organ Kesme Cezasinda}

Hasta olan mahkûmun organ kesme cezasının infazı sebebiyle mahkûmun hayatı tehlikeye girecekse infaz, mahkûmun sağlığına kavuşmasına veya infaz sebebiyle ek zararlar ortaya çıkmayacak duruma gelmesine kadar ertelenir. ${ }^{43} \mathrm{Bu}$ durum İslam hukuku açısından hırsızlık sebebiyle el kesme, kısasen organ kesilmesi veya hırabe suçu sebebiyle el- ayak kesme cezalarında söz konusu olabilir.

\section{Celde Cezasinda}

Had suçları kapsamında vurulan sopa cezasına celde denir. Muhsan olmayanın zinası ile kazif suçlarına celde; içki içme (şürb) suçuna darb cezaları öngörülmüştür. Mahkûmun hastalığının kendisine verilen celde cezasının infazını durdurup durduramayacağı konusunda mezhepler arasında görüş ayrılığı bulunmaktadır.

Hanbelilere göre celde cezası derhal uygulanır ve ertelenmez. ${ }^{44} \mathrm{Bu}$ görüşün temeli Hz. Ömer'in halifeliği devrinde Kudame b. Maz'un isimli birine hasta olduğu halde celde cezasını tatbik etmesidir. Halifenin bu uygulamasına sahabeden bir itiraz gelmemesi bu konuda sahabe icmaı bulunduğunu göstermektedir. Hanbelilerin bu görüşte olmas1 mahkûmun hastalığının infaza hiçbir etkisinin bulunmaması görüşünde olduklarını göstermez. Onlar infazda kullanılan aletler açısından bir hafifletmeye gidilmesi görüşündedirler. Örneğin hastanın ölümüne yol açmayacak şekilde ince bir dalla veya bu bile ağır gelecekse; eğer ceza 100 celde ise, elli veya yüz daldan oluşacak bir demetle bir veya iki defa vurularak infazın tamamlanabileceği görüşündedirler. ${ }^{45}$ Bu görüşe gerekçe

42 SERAHSİ, 2008, C.9, No:101; HALEBİ, 1968, C.2, s.274; FETAVA-YI HINDIYYYE, 2004, C.4, s.18; İBN ABIDIN, 1983, C.8, s.187; UDEH, 2012, C.1, s.762; MEZURİ, 2017, s.872-873; ÖZGÜR, 2020, s.113.

43 EBU ZEHRA, 1994, C.2, No:234.

44 EBU ZEHRA, 1994, C.2, No:233; BİLMEN, 1970, C.3, s.227; AVCI, (I), s.445.

45 FETAVA-YI HINDIYYE, 2004, C.4, s.17; UDEH, 2012, C.1, s.762; EBU ZEHRA, 1994, C.2, No:233; MEZURİ, 2017, s.873; ÖZGÜR, 2020, s.114. 
olarak Kur'an'daki Hz. Eyyub'a yönelik “eline bir demet bitki sapı alıp onunla vur ve böylece yeminini yerine getirmiş ol (dedik)" ( Sâd, 38/44) ayetini gösterirler.

Hanefiler, Malikiler ve Şafiiler ise mahkûmun hastalığının celde cezasını infazını erteleyeceği görüşündedirler. ${ }^{46} \mathrm{Bu}$ görüşün temeli Hz. Ali’nin bir uygulamasıdır. Hz. Peygamber zina etmiş olan bir cariyeye celde cezasını infaz etmesini Hz. Ali’ye emretmiştir. Hz. Ali infaz için cariyenin yanına gidince onun henüz doğum yapmış olduğunu görmüş ve celde vurması halinde cariyenin ölebileceğini düşünerek infazı yapmadan gelip durumu Hz. Peygamber'e anlatınca o da "İyi yapmışsın" demiştir. ${ }^{47}$ Dolayısıyla doğumdan sonraki lohusalık dönemi hastalık dönemi kabul edilmiş ve mahkûmun infazının ertelenmesi sonucunu ortaya çıkarmıştır. ${ }^{48}$ Bir görüşe göre ise maslahata göre had cezasının hemen uygulanması gerekiyorsa mahkûmun hastalığına uygun bir aletle celde cezası infaz edilir. Maslahata göre celde cezasının hemen uygulanmas1 gerekmiyorsa ceza ertelenir.

Eğer mahkûmun hastalığının iyileşme imkânı yoksa celde cezasının hemen infaz edilmesi gerekir. İyileşme imkânı olmayan hastalık mahkûmun ölümüne kadar devam edeceği için infazı ertelemeyi gerektiren bir sebep de bulunmamaktadır. ${ }^{49}$ Hadlerin hemen infazı emredildiğinden de infaz ertelenmeden gerçekleştirilmelidir. Bu görüşe gerekçe olarak Hz. Peygamber'in bir uygulaması gösterilebilir. Buna göre zina ettiği kesinleşmiş bir adamın durumu Hz. Peygamber'e bildirilmiş, o da adama yüz celde vurulmasını emretmişti. Bunun üzerine Said b. Ubade adamın zayıf bünyeli olduğu ve bu ceza infaz edilecek olursa ölebileceğini söylemiştir. Hz. Peygamber de içinde yüz tane dal bulunan demetle bir defa vurulmak suretiyle cezasının infaz edilmesini emretmiştir. ${ }^{50}$

46 SERAHSİ, 2008, C.9, No:100; ŞİRBİNI, 2017, C.16, s.252-253; FETAVA-YI HİNDİYYE, 2004, C.4, s.17; UDEH, 2012, C.1, s.762; EBU ZEHRA, 1994, C.2, No:233.

47 Müslim, Hudud, 34, Tirmizi, Hudud, 13; Ebu Davud, Hadis no: 3764; EBU ZEHRA, 1994, C.2, No:232.

48 SERAHSİ, 2008, C.9, No:73.

49 ŞİRBİNİ, 2017, C.16, s.253; BİLMEN, 1970, C.3, s.195.

50 İbn Mace, Hudud, 18; Ebu Davud, Hudud, Hadis No: 4472. 


\section{Dayak Cezasında}

Bir kimseye dayak cezası verilip infaz edildikten kısa bir süre sonra tekrar dayak cezasını gerektiren bir suç işlerse cezanın infazı önceki infazdan kaynaklanan yaraların iyileşmesine, acısının hafiflemesine kadar ertelenir. Bu sürede suçlu hapsedilir. ${ }^{51}$

\section{Diğer Cezalarda}

Hastalık diğer türden cezaların infazının ertelenmesi için de bir sebep olabilir. Bunun en büyük örneği hapis cezasında karşımıza çıkar. Hapis cezası infaz edilirken hastalanan kişi, eğer hapishanede imkân yoksa hapishane dışında hastanede tedavi ettirilir. ${ }^{52}$ Suçlunun hapishane dışındaki hastanede geçirdiği süre de hapis cezasına sayılır.

Osmanlı uygulamasında mühimme defterlerine yansıyan bir örnekte kürek cezası alan mahkûmlar cezayı çektikleri gemide hastalanınca karaya çıkarılıp tedavi amacıyla ilgili memurlara teslim edilmişlerdir. ${ }^{53}$ Osmanlı 1851 Ceza Kanunu Üçüncü Fası1 m.16'da: “Ale'l-ıtlak mahpus olanlardan ă̆ırca hasta olanların kavî kefile rabtryla tahsil-i bür'-i tam edinceye kadar hanelerinde ikamet ve tedavi eylemelerine ruhsat verilip eyyam-ı hastalıkları müddet-i muayyene-i mahbusiyetlerine mahsub oluna ve bu vechile hasta olduğu cümle indinde tebeyyün ederek ruhsat verilen mahbusun kesb-i ifakat edip etmedikleri on beş günde bir kere tahkik olunmasına ol beldenin umur-l mülkiyesine memur tarafindan dikkat kılına." denilerek hapis cezasını çeken mahkûmların ağır hasta olmaları halinde kefile bağlanarak evlerine gönderilmeleri, evlerinde geçirdikleri sürenin hapis cezasından sayılması, hastalığının iyileşip iyileşmediğini tespit için yetkililerin on beş günde bir mahkûmun durumunu kontrol etmeleri hükme bağlanmıştır. Bir başka arşiv belgesine göre kendisine sürgün cezası verilen Abdurrahman Efendi, hasta olduğu için cezasının infazı ertelenmiş, bunun haber

51 EBU YUSUF, 1973, s.261; AVCI, 2004, s.107.

52 İBN ABİDIN, 1983, C.12, s.170; AVCI, 2004, s.137.

53 “Darende Yorgi nam zimmi gelip nefs-i İmir'de kefere kethüdası olup sene-i sabıkada donanma-yı hümayunum ol canibe vardıkta, kaptanım kürekte olan mücrimlerden on üç nefer kimesneyi mariz olmağın kendüye tımar etmek için teslim olunup mezburlar ifakat bulup habs olunmuşlar iken...” 3 Numaralı Mühimme Defteri, Hüküm No: 113. 
alınması üzerine yetkili makamlar infazın ertelenmeksizin hemen yerine getirilmesini yerel yöneticilere emretmişlerdir. ${ }^{54}$

\section{Kısas İsteme Hakkına Sahip Olan Kimsenin Akıl Hastası, Küçük veya Gaip Olması}

Bir kişiyi öldürdüğü için kısasen ölüm cezasına çarptırılan mahkûmun cezasının infazı maktulün mirasçılarının isteği üzerine gerçekleştirilir. Eğer mağdurun yakınları mahkûmun öldürülmesini istemezlerse ya diyet talep edebilirler veya bir karşıllk olmaksızın mahkûmu affedebilirler. Kısas isteme hakkı kişiye sıkı sıkıya bağlı olan haklardandır. Öyle ki baliğ olmamış çocuğun veli veya vasisi çocuğun yerine bu hakkı kullanamazlar. Aynı durum akıl hastası ve gaip kimse için de geçerlidir. Eğer akıl hastalığı geçici, mevsimsel, belirli zamanlarda gelip geçen bir şekildeyse hastanın akli melekelerini tam olarak kullanabilmeye başlayacağı zamana kadar beklenir. Aynı şekilde bir yere gidip kendisinden haber alınamayan gaip kimsenin de gelmesine kadar beklenir. Küçüğün ise buluğa erişip kısas isteme hakkını kullanabileceği zamana kadar beklenir, infaz bu sürelere kadar ertelenmiş olur. ${ }^{55}$

Osmanlı kadı sicillerine yansıyan bir örnekte efendisini öldüren bir köleye verilecek olan kısas cezasının infazı efendisinin küçük oğlunun buluğa ermesine kadar ertelenmiştir: “Babası bundan akdem maktûlen fevt olan Ali Bey'in Mustafa nâm sagīr oğluna tesviye-i umûru için kıbel-i şer'den mansûb vasî olan fahrü'l-akrân Şaban Ăga b. Abdülmennân meclis-i şer'de hazır oldu. Onunla birlikte müteveffâ-i mezbûrun abd-i sâbıkı olan Rûsiyyü'l-asl Yusuf b. Abdullah nâm gulâm da hazır oldu. Vasîyy-i merkūm, zeyilde mezkûr senenin Ramazân-ı mübârekinin on dördüncü gecesi gulâm-ı mezkûrun

54 BOA, Ali Emiri Mustafa III. (AE.SMST.III) 49/3565. H-29-12-1173.

55 EBU YUSUF, 1973, s.254; İBN KUDAME, Ebu Muhammed Abdullah b. Ahmed, el-Muğni Muhtasarı, Kısaltan ve yayına hazırlayan Hamed b. Abdülaziz el-Hammad, çev. A. A. Tunçer, Karınca-Polen Yayınları, İstanbul, 2015, C.4, s.306; MERĞİNANİ, Burhaneddin Ali b. Ebu Bekr, elHidaye, (Delilleriyle Hanefi Fıkhı), (çev. A. Meylani), Kahraman Neşriyat, İstanbul, ty., C.4, s.258; ŞİRBİNi, 2017, C.15, s.188; FETAVA-YI HINDIYYYE, 2004, C.12, s.477; BİLMEN, 1970, C.3, s.94; ZUHAYLİ, 1994, C.8, s.68; ÖZGÜR, 2020, s.117. Erteleme süresi boyunca katil hapsedilir. İBN KUDAME, 2015, C.4, s.307. Hz. Muaviye de halifeliği zamanında bir kişiyi öldüren katili, ölenin oğlunun buluğa ermesine kadar hapsetmişti. Sahabe döneminde gerçekleşen bu olaya bir itiraz gelmediği için bu konuda sahabe icmaı vardır. BİLMEN, 1970, C.3, s.94; EBU ZEHRA, 1994, C.2, No:354. 
keskin bir âlet-i câriha ile efendisi mezbûru amden katlettiğini iddia ve kısas talep etti. Gulâm-ı mezkûra soruldukda efendisini vech-i meşrûh üzre katlettiğini tâi'an ikrar ve itiraf etti. Hâkim de kütüb-i şer ‘yyede musarrah olduğu üzere imâmeynin kavline iktidâen sagīr-i mezbûrun bülûğuna kadar kısasın durdurulmasına hükmetti. 20 Zilhicce 1042." $" 56$

Bir başka örnekte ise bir zimmiyi öldüren başka bir zimmiye verilecek olan kısas cezası ölenin yakınlarının başka bir yerde oturması nedeniyle kendilerinin gelmesine kadar ertelenmiştir: "hâlik-i mesfûrun zevcesi ve anası mesfûretân Agafile ve Gülistan Nasrâniyeler Zelli karyesinde mütemekkinler olup mûceb-i şer'îsini istîfâda mezbûretânın huzûrları lâzım olmă̆ın mesfûretân Âsitâne-i saâdete gelinceye değin mûceb-i şer 'îsi tevkīf ve mezbûr Ligor'u habs olunmak iktizâ eylediği huzĥr-l âlîlerine ilâm olundu. 24 Muharrem 1153.,"57

$\mathrm{Bu}$ durumlarda infazın ertelenmesinin sebebi kısas isteme hakkına sahip olan kimsenin kısastan vazgeçmesi ihtimaline binaendir. Akıl hastası, küçük veya gaip olan kişi tam ehliyetli hale gelirse mahkûm ile sulh olarak ya diyet karşılığı veya karşılıksız olarak kısastan vazgeçebilir. Mahkûm açısından da ölüm yerine hapishanede beklemesi bu ihtimalin varlığı sebebiyle daha olumludur. Kısas isteme hakkına sahip olan kişi açısından ise diyet karşıllı̆ı uzlaşıp maddi kazanım elde etme ihtimali olumlu olduğu için her taraf açısından da olumlu sonuçlar doğurabilme ihtimali infazın ertelenmesi sonucunu ortaya çıkaracaktır. 58

\section{Mağdurun Yarasının İyileşmesinin Beklenmesi}

Yaralama suçlarında mağdurun yarasının iyileşmesine kadar faile verilecek olan kısas cezası ertelenir. Bunun sebebi mağdurun yarasından dolayı suçun neticesi sebebiyle ağırlaşma ihtimalidir. Çünkü bu yara sebebi ile ölüm veya organ kaybı söz konusu olursa

56 Rumeli Sadareti Mahkemesi 56 Numaralı Sicil (H.1042-1043/M. 1633) cilt: 14, sayfa: 56 Hüküm no: 20.

57 Bab Mahkemesi 172 Numaralı Sicil (H. 1152-1153 / M. 1740) cilt: 69, sayfa: 457 Hüküm no: 559.

58 ÖZGÜR, 2020, s.118. Akıl hastası olan kişinin maddi durumu iyi değilse ve paraya ihtiyacı varsa katil diyet karşıllı̆ı affedilebilir. BİLMEN, 1970, C.3, s.94. 
ceza da ona göre ağırlaştırılacaktır. ${ }^{59} \mathrm{~Hz}$. Peygamber'in uygulamasında bu durum görülmektedir: Bir adam başka birisinin boynuz parçası ile kendisini yaraladığını söyleyerek Hz. Peygamber'den kısasen diğer adamın da yaralanmasını talep etmiştir. Hz. Peygamber ise bu adama acele etmemesini söyleyerek yarasının iyileşmesinin beklenmesini tavsiye etmiştir. Ancak adam beklemeyip failin hemen kısas edilmesini istemiş, bunun üzerine Hz. Peygamber de kısasen faili yaralanmasına hükmetmiştir. Daha sonra mağdur olan kişinin ayağı yarasından dolayı topal kalmış ve uzvu işlevini yitirmiştir. Failin yarası ise iyileşmiştir. Mağdur olan adam tekrar Hz. Peygamber'e gelip kendi ayağının topal kaldığını, failin ise yarasının iyileştiğini belirtip tekrar kısas istemiş. Bunun üzerine Hz. Peygamber "Yazıklar olsun sana! Ben sana yaranın iyileşmesine kadar beklemeni söylemiştim; ama sen beni dinlememiştin." demiştir. ${ }^{60}$ Bu olaydan sonra Hz. Peygamber yaralama suçlarında mağdurun yarası iyileşene kadar infazın ertelenmesini emretmiştir. Bir başka rivayette ise Hz. Peygamber mağdurun yarası iyileşene kadar faile verilecek cezayı ertelemiştir. ${ }^{61}$

Osmanlı uygulamasında yaralama suçlarında faile verilecek cezanın, mağdurun yarasının iyileşmesine kadar beklenmesine kadı sicillerinde çokça rastlanmaktadır. “mezbûru sol boş böğründen darb ve cerhini ahrâr-ı ricâl-i Müslimînden lede't-tezkiye adâletleri zâhir olan Molla Osman b. Süleyman ve Molla İbrahim b. Murad nâm kimesneler şehâdetleriyle mezbûr Molla Abdurrahman muvâcehesinde ba 'de'l-isbât ve'lkabûl mûceb-i şer 'îsiyle hükm cerh-i mezkûrun bür'ine tevkîf olunmak iktizâ eylediği Mahkeme-i Bâb'dan huzûr-ı âlîlerine ilâm olundu. 4 Cumâdelâhire 1162. "62

59 BİLMEN, 1970, C.3, s.80.

60 Aḥmed b. Hanbel, Ebû Abdullâh Aḥmed b. Muhammed b. Hanbel eş-Şeybânî, el-Müsned (nşr. Şu 'ayb el-Arnavût, Âdil Murşid v.dğr), Müessesetü'r-Risâle, 1421/2001, XI, 606; ÖZGÜR, 2020, s.122.

61 Dârekutnî, Ebû'l-Ḥasen Alî b. Ömer el-Bağdâdî, Sünenu'd-Dârekutnî, I-V, Müessesetü'r-Risâle, Beyrut 1424/2004, IV, 71.

62 Bab Mahkemesi 197 Numaralı Sicil (H. 1162-1163 / M. 1749-1750) cilt: 73, sayfa: 207 Hüküm no: 186. 
"mezbûr Mehmed Beşe muvacehesinde vech-i şer'î üzere isbât etmeğin mûceb-i şer 'îsi müdde 'î-i mezbûr es-Seyyid el-Hâc Hasan'in cerhinin bür'-i tâmmına tevkīf olunduğu huzûr-ı âlîlerine ilam olundu. 22 Rebî̈levvel 1162. "63

“cürûh-ı mezkûrun hükmü bür'-i tâm husûlüne tevkîf iktizâ eylediği bi'l-iltimâs huzûr-ı âlîlerine Mahkeme-i Bâb'dan ilâm olundu. 3 Şaban 1162. "64

\section{IV. İnfaz Yapılacak Ortamın Uygun Olmaması Sebebiyle Erteleme}

İnfaz yapılacak ortamın uygun olmaması nedeniyle infazın erteleme sebepleri infazın yapılacağı yerdeki hava koşullarının uygun olmaması ve suçun savaş sırasında işlenmesidir.

\section{A. Olumsuz Hava Koşulları}

İnfaz yapılacak yerdeki olumsuz hava koşulları nedeniyle cezası infaz edilecek olan mahkûmun sağlığının kötü etkilenmesi ihtimaline binaen İslam hukukçuları bazı cezaların infazının ertelenmesi gerektiği görüşündedirler. Cezalar açısından bakacak olursak: Kısasen ve hadden öldürme suçlarının infazı hava koşulları sebebiyle ertelenemez $^{65}$; çünkü ceza sonucunda mahkûm zaten ölecektir. Kısasen veya hadden organ kesilmesi veya celde cezasında havanın çok soğuk veya sıcak olması mahkûmun kanının durmamasına, yarasının iyileşmesini geciktirmeye sebep olabileceği için ertelenmelidir. Hanefi, Maliki ve Şafiiler bu görüştedir. ${ }^{66}$ Hanbeliler ise had cezasının

63 Bab Mahkemesi 197 Numaralı Sicil (H. 1162-1163 / M. 1749-1750) cilt: 73, sayfa: 111 Hüküm no: 37.

64 Bab Mahkemesi 197 Numaralı Sicil (H. 1162-1163 / M. 1749-1750) cilt: 73, sayfa: 277 Hüküm no: 308. Benzer hükümler için bakınız: Üsküdar Mahkemesi 403 Numaralı Sicil (H. 1154-1155 / M. 1740-1742) cilt: 70, sayfa: 196 Hüküm no: 330; Eyüp Mahkemesi 182 Numaralı Sicil (H. 1154-1161 / M. 1741-1748) cilt: 72, sayfa: 189 Hüküm no: 220; Konya Kadı Sicilleri Defter 45, haz. İzzet Sak, Cemal Çetin, Konya, 2016, sayfa 143-144, Hüküm no: 72-4.

65 ŞİRBİNi, 2017, C.15, s.205; BİLMEN, 1970, C.3, s.93; UDEH, 2012, C.1, s.762. Had cezasının infazına başladıktan sonra da olumsuz hava koşulları sebebiyle infaz yarıda kesilemez. FETAVA-YI HİNDIYYE, 2004, C.4, s.19. Hava koşularından dolayı infazı ertelenen dayak cezasında fail bu erteleme süresince hapsedilir. AVCI, Mustafa, Hukuk Tarihimizde Hapis, 2.Bask1, Adalet Yayınevi, Ankara, 2019, s.202.

66 SERAHSİ, 2008, C.9, No:185; İBN RÜŞD, Ebü'l-Velîd Muhammed b. Ahmed b. Muhammed elKurtubî, Bidâyetü'l-Müctehid ve Nihâyetü’l-Muktesıt, (çev. A. Meylani, Redaksiyon ve Düzenleme: V. Akyüz), Ensar Neşriyat, İstanbul, 2015, C.3, s.568; ŞİRBİNi, 2017, C.16, s.255-256; FETAVA-YI 
ertelenmeden hemen uygulanması düşüncesinden hareketle infazın ertelenemeyeceği görüşündedirler. ${ }^{67}$

Hanefi, Maliki ve Hanbelilere göre şahıs haklarına yönelik işlenen suçların cezasının infazı hava şartları sebebi ile ertelenmelidir. ${ }^{68}$ Şafiiler ise bu konuda farklı görüşte olup infazın ertelenmesinin şahıs hakkının zayi edilmesine sebep olabileceği ihtimaline binaen infazın ertelenemeyeceği görüşündedirler. ${ }^{69}$

Osmanlı arşiv kayıtlarına yansıya bir örnekte Nasuhoğlu ve Curaoğlu isimli iki suçluya verilecek olan cezaların infazı kışın şiddetli geçmesinden dolayı bahara ertelenmiştir. $^{70}$

\section{B. Savaș Hali}

Savaş için sefere çıkan bir ordu içindeki bir kimsenin bir suç işlemesi halinde cezasının infazının ertelenip ertelenemeyeceği konusunda görüş ayrılıkları vardır. Hanefi ve Hanbeliler, ordu darülislam denilen İslam topraklarından çıkıp darülharp denilen düşman topraklarına giderse "Harp ülkesinde had cezaları uygulanmaz","1 ve "Savaşta yapılan hırsızlıkta el kesme yoktur"72 hadislerini temel alarak infazın savaş sonrasına ertelenmesi görüşündedirler. Bu görüşün bir diğer gerekçesi ise kendisine ceza uygulanan kimsenin düşman saflarına katılarak İslam ordusunu tehlikeye atabileceği ihtimalidir. ${ }^{73}$

HIINDIYYY, 2004, C.4, s.18, 120; BILLMEN, 1970, C.3, s.95; ZUHAYLİ, 1994, C.7, s.359. Bu süre boyunca mahkûm hapsedilecektir. BEHNESİ, 1961, s.217; MEZURİ, 2017, s.876.

67 İBN RÜŞD, 2015, C.3, s.568; BİLMEN, 1970, C.3, s.227; AVCI, (I), s.444; MEZURİ, 2017, s.876; ÖZGÜR, 2020, s.123.

68 SERAHSİ, 2008, C.9, No:101; ZUHAYLİ, 1994, C.8, s.130; ÖZGÜR, 2020, s.122.

69 SERAHSI, 2008, C.9, No:168-169; ŞíRBİNİ, 2017, C.16, s.256.

70 BOA, Ali Emiri Selim III (AE.SSLM.III), 189/11392. H-29-12-1207.

71 BEYHAKİ, Ebû Bekr Ahmed b. el-Ḥuseyn b. Alî el-Husrevcirdî, es-Sunenu'l-Kubrâ (nşr. Muhammed Abdulkâdir Atâa), Beyrut 1424/2003, IX, 178; ZEYLE'İ, Ebû Muhammed Abdullâh b. Yûsuf, Nasbu'rRâye li Ehâdîsìi'l-Hidâyeti me'a Ḥâşiyetihî Buğyeti'l-Elme'î fî Tahrîci'z-Zeyle î̀ (nşr. Muhammed Avvâme), I-IV, Muessesetu'r-Reyyân Beyrut, Dâru'l-Kible li's-Sekâfeti'l-İ́slâmiyye, Cidde 1418/1997, III, 343.

72 Ebu Davud, Hudud, 19; Tirmizi, Hudud, 20.

73 SERAHSI, 2008, C.9, No:100; İBN KAYYIM, el-Cevziyye, Şemsüddin Ebu Abdullah Muhammed b. Ebu Bekr, İ'lamü'l-Muvakkı'in, (çev. P. Düzenli), Pınar Yayınları, İstanbul, 2017, C.3-4, s.38-39; AVCI, (I), s.71; ARSLAN, Adem, İlk Devir İslam Ceza Hukukunda Had Cezalarının İnfazı, Harran 
Maliki ve Şafiilere göre ise bir had cezası ister darülislam isterse darülharp'te işlensin cezasının hemen verilmesi gerekir. Dolayısıyla savaş hali infazın ertelenmesi için bir sebep olamaz. Bu mezhepler cezası infaz edilen kimsenin düşman saflarına katılabilme ihtimaline ise şu hadisle cevap vermişlerdir: "Allah yolunda yakında veya uzakta düşmanlara karşı cihad edin. Allah uğrunda hiçbir kimsenin kınamasına aldırış etmeyin ve Allah'ın koyduğu had cezalarını gerek ikamet ve gerek yolculuk durumlarında uygulayın. "74

$\mathrm{Bu}$ ertelemeye örnek olarak gösterilecek bir olay şu şekilde yaşanmıştır: Ebu Mihcen isimli bir kimse içki bağımlılığı olan bir kimseydi. Hz. Ömer devrinde de bu suçtan dolayı ceza almıştı. Kadisiye savaşı sırasında yine içki içmekten dolayı tutuklanmış ve hapsedilmişti. Daha sonra orduya katılmak için zincirlerinden kurtulan Ebu Mihcen savaşın çok zorlu geçtiği bir sırada savaşa katılmış ve gösterdiği üstün cesaret ile ordunun savaşı kazanmasına katkı sağlamış bunun üzerine ordu komutanı olan Sa'd b. Ebi Vakkas onun cezasının infazından vazgeçmiş, Ebu Mihcen de bir daha içki içmemiştir. ${ }^{75}$

Bir başka örnekte ise Alkame adlı bir sahabenin anlattığına göre Bizans toprağında savaşırlarken ordunun başında Velid b. Ukbe adlı birisi bulunuyordu. Bu kişi şarap içince onu cezalandırmak istemişler, Huzeyfe isimli sahabe ise "Düşmanınıza yaklaşmışken komutanınıza had cezası mı uygulayacaksınız? Bu size karşı düşmanınıza cesaret verir”, demiş, böylelikle içki içme suçunun infazı ertelenmiştir. ${ }^{76}$

Üniversitesi Sosyal Bilimler Enstitüsü, Yayımlanmamış Yüksek Lisans Tezi, Şanlıurfa, 2005, s.22; MEZURİ, 2017, s.874-875; ÖZGÜR, 2020, s.124.

74 MEZURI, 2017, s.875.

75 İBN KAYYIM, 2017, C.3-4, s.39-40; TALU, Mehmet, “Ebu Mihcen”, DİA, İstanbul, 1994, C.10, s.188; AVCI, (I), s.445.

76 İBN KAYYIM, 2017, C.3-4, s.39; KARAMAN, Hayreddin, İslam Hukukunda İctihad, 3. Bask1, DİB Yayınları, Ankara, 1985, s.70; AVCI, Mustafa, Osmanlı Ceza Hukuku Özel Hükümler (II), 3. Baskı, Adalet Yayınevi, Ankara, 2018, s.408. 


\section{Farklı Sebeplerle Erteleme}

Osmanlı uygulamasında daha önce belirtilen sebepler dışında birçok nedenle cezaların infazının ertelendiği veya ertelenmesinin talep edildiğine rastlanmaktadır. $\mathrm{Bu}$ örneklere göre: Vahşi bir kavmin zararından kaçınılmak için bu kavimden olan kişilere verilecek olan cezaların tehir edildiği görülmektedir. ${ }^{77}$ Yabancı devletlerin elçilikleri Osmanlı devleti içinde idam cezasına mahkûm olan Hristiyanların cezalarının ertelenmesini talep etmişlerdir. ${ }^{78}$ Priştine, Novabırda ve Vulçıtrın kazaları müdürü Malik Paşa'nın tüm adamları ve yakınları ile beraber Sofya'ya sürgün edilmesine karar verilmişken orada Arnavut eşkıyasının ortaya çıkmasından dolayı bu sürgün cezaları ertelenmiştir. ${ }^{79}$ Beypazarı Voyvodası Topal Ağa’nın idam cezasının Kara Osman’ın idamından sonraya ertelenmesi uygun görülmüştür. ${ }^{80}$ Adana Ceza Mahkemesi tarafından idam cezasına çarptırılan yedi Ermeni'nin infazlarının bir süre ertelenmesini Fransa elçisi rica etmiş, bunun üzerine yapılan araştırma neticesinde cinayet ile suçlanan iki Ermeni'nin idam cezası onanmış, suç ortağı olan iki kişiye ise müebbet kürek cezası verilmiştir. ${ }^{81}$ Süleyman isimli bir suçlu sürgün cezası alarak bu sürede hapsedilmiş, failin annesi Ayşe Sıdıka Hanım da bunun üzerine kendisine bakacak kimsesi olmadığı için bu cezanın ertelenmesi talebinde bulunmuş ve failin cezası ertelenmiştir. ${ }^{82}$ Sinop'a bağlı Kinaki ahalisinden Tığlığlu Mustafa, Bolu'ya bağlı Mengen müdürü Feyzi Ağa ile rüşvet alış-verişi yapmış. Bunun üzerine kendisine verilen para cezasını ödemeye gücü yetmediği için bu cezanın infazı müsait bir zamana ertelenmiştir. ${ }^{83}$ Rusya Elçiliği baş tercümanı Başkâtibe gelerek Karayoryanik'in katilinin idamının ertelenmesinden duydukları rahatsızlığı bildirmişlerdir. Bir ilginç örnekte ise İskeçe Hapishanesi’nin

77 BOA, Sadaret Mektubi Mühimme Kalemi Evrakı (A.MKT.MHM), 226/13. H-07-01-1278.

78 BOA, Yıldız Perakende Evrakı Hariciye Nezareti Maruzatı (Y..PRK.HR), 18/49. H-02-08-1311.

79 BOA, Hatt-1 Hümayun (HAT), 339/19419. H-19-12-1237.

80 BOA, Hatt-ı Hümayun (HAT), 494/24280. H-03-05-1231.

81 BOA, Sadaret Mektubi Mühimme Kalemi Evrakı (A.MKT.MHM), 617/9. H-20-04-1314.

82 BOA, Dahiliye Nezareti Mektubi Kalemi (DH.MKT), 352/16. H-12-09-1312.

83 BOA, Sadaret Mektubi Kalemi Meclis-i Vala Evrakı (A.MKT.MVL), 145/35. H-24-10-1278. Benzer bir hükme göre ormandan kesilmesi için işaretlenmiş ağaçlar dışındaki ağaçlardan kesim yapan İzmirli Mustafa Nail Efendi’ye verilen para cezasına ödemeye gücü yetmediği için verilen cezanın infazı ertelenmiştir. BOA, İrade Hususi (İ.HUS), 168/72. H-22-06-1326. 
darlığı ve kadın hapishanesi bulunmaması dolayısıyla mahkûmların cezaları ertelenmiştir. ${ }^{84}$ Filibe'de hapsedilen Keşovoğulları hakkında yapılacak yargılama sonucunda idam veya başka bir ceza verilirse İngiltere'nin desteğinin kaybedilmesi söz konusu olacağından, bunlar yargılama sonucunda bir ceza alırlarsa Dersaadet'ten emir gelinceye kadar infazlarının ertelenmesi Filibe Kumandanına bildirilmiştir. ${ }^{85}$ Bazı kimselere verilen cezaların infazı ise sefere katılmaları karşılığında ertelenmekteydi. $\mathrm{Bu}$ hususta verilen bir emre göre süvari sekban levendatı eşkıyasından olup yol kesme, adam öldürme, yağma yapma suretiyle halka zulmeden suçluların cezalarının infazı sefere katılmaları şartıyla ertelenmiş, bu fiilleri yapmaya devam etmeleri üzerine cezalandırılmaları emredilmiştir. ${ }^{86}$

Yukarıda bahsedilen örneklerdeki infazın ertelenmesi sebeplerinden en çok dikkat çekeni irtidat fiilinden dolayı idamına hükmedilen gayrimüslimlerin idam cezalarının ertelenmesini isteyen yabancı elçiliklerin taleplerinin dikkate alınmasıdır. Bu konuda ilk olarak yabancı elçiliklere devletin iç işlerine karışmamalarını istirham eden ${ }^{87}$ Osmanlı devleti daha sonra Batılı devletlerin bunu Hristiyanlığın aleyhine bir durum ve insan haklarına aykırı bir hareket olarak görmeleri üzerine şu kararı almıştır: "Şu zamanda bir mürted zuhur etse icra-yı ceza-yl fiiliyesini bizzarure cüret olunamayacağl, göze alınıp da icra kılınırsa Avrupa'ya karşı alınmış bir tavır ve husumet olarak değerlendirileceği, böyle bir durumda ise Avrupa'nın gizli veya gerçek maksatlarını tahakkuk için harekete geçecekleri, hatta bununla kanaat etmeyerek, türlü türlü tekliflerle teşebbüs ve icrasına Devlet-i Aliyye'yi mecbur edecekleri görülmüştür. İş bu raddeye gelince de bunun çaresinin bulunamayacă̆l zaten bellidir. Bu maddeyi Osmanlı ulema ve Vükelasının hiçbirinin tecviz ve kabul tarafinda bulunamayacă̆l açıktır. Ancak, Avrupa Devletleri'nin aradıkları firsatı ellerine vermemek ve zaman kazanmak ve de Allah'in

BOA, Dahiliye Nezareti Mektubi Kalemi (DH.MKT), 2527/107.H-17-05-1319.

BOA, Mabeyn-İrâde (MB.İ), 40/29. H-18-09-1294.

86 BOA, Bab-ı Asafi Divan-ı Hümayun Sicilleri Mühimme Defterleri (A.DVNSMHM.d), 127/907. H30-09-1130.

87 “Reşit Paşa, Paris elçisi Nafi Efendi ile birlikte Fransa Dışişleri Bakanı Guizot'u ziyaret ederek dost devletlerin Devlet-i Aliyye'yi müşkül durumda bırakmamalarını gayri resmi olarak rica etmişlerdir." AVCI, (II), s.537. 
lütfuyla kuvvetli olmak gerekmektedir. " ${ }^{\circ 8} \mathrm{Bu}$ ifadeler irtidat suçunu işleyen kişilerinin cezalarının hemen verilmeyip infazlarının ertelenmesine karar verileceğini göstermektedir. ${ }^{89}$

\section{SONUÇ}

İslam hukukunda infazın her durumda ve her zaman yapılmasının gerekmediği belirli bazı durum ve şartların varlığı halinde infazın ertelenebileceği haller vardır. İnfazın ertelenmesi bazı durumlarda mahkûmun lehine gibi görünürken bazı durumlarda mağdurun dahi lehine sonuçlar doğurabilir. Bu açıdan infazın ertelenmesi kurumunun tarihteki ilk örneğini İslam hukuku vermiştir denilebilir. Sonraki hukuk sistemleri infazın ertelenmesi kurumunu çok daha sonraları uygulamaya başlamışlardır. Buradan şu sonuç çıkarılabilir: İslam hukukuna göre mahkûmun her ne suretle olursa olsun cezalandırılması yerine cezalandırmanın caydırma ve mahkûmun ıslahı amaçları daha çok önemsenmektedir. Mahkûmun cezalandırılmasından dolayı başka suçsuz kimseler de zarar görecekse, mahkûmun ıslahı tam olarak sağlanamayacaksa, mahkûmun acısı normalden daha çok olacaksa, Müslümanlar savaşta zarar görecekse, mağdurun mağduriyetinin giderilmesine firsat verilmeyecekse infazın ertelenebileceği görülmektedir. Osmanlı uygulamasında ise bu sebeplerden başka siyasi ve politik sebeplerle de infazın ertelenebildiği görülmektedir. $\mathrm{Bu}$ sebeplerin ise devletin zayıflamaya başladığı tarihlerde çoğalması dikkat çekmektedir.

İnfazın ertelenmesinin genellikle bedeni cezalarda tezahürü söz konusu olmaktaysa da özellikle Osmanlı uygulamasında kendilerine verilen para cezasını ödeme güçlüğü çeken kimselerin bu cezalarının infazının ödeyebilecek duruma gelmelerine kadar ertelendiği de görülmektedir. Osmanlı'da Tanzimat dönemindeki kanunlarda çok az bir şekilde rastlanılan infazın ertelenmesi kurumuna özellikle 1879 tarihli Usul-1 Muhakemat-1 Cezaiyye Kanunu'nda rastlanmaması oldukça dikkat çekicidir. Bu durum Batı hukukunda infazın ertelenmesi kurumuna o devirlerde rastlanmaması ve Batı'dan

88 ÖZÇELİK, Selahittin, “Osmanlı İ̧̧ Hukukunda Zorunlu Bir Tehir (Mürted Maddesi)”, OTAM Ankara Üniversitesi Osmanlı Tarihi Araştırma ve Uygulama Merkezi Dergisi, C.11, Sy:11, 2000, s.415.

89 AVCI, (II), s.537. 
alınan bu kanunda da bundan dolayı hüküm bulunmamasıyla açıklanabilir. Ayrıca Tanzimat devrindeki diğer ceza kanunlarında da İslam hukukundaki infazın ertelenmesi sebeplerinin hepsine değil sadece birkaç tanesine rastlanmaktadır. İnfazın ertelenmesi kurumu İslam ceza hukukunun infazın insaniliği, cezaların şahsiliği, suçlunun ıslahı, mağduriyetin giderilmesi gibi hususlara oldukça dikkat ettiğinin bir göstergesidir. Sonuç olarak adalet her zaman cezanın hemen infaz edilmesi ile sağlanamaz.

\section{KAYNAKÇA}

ACAR, Betül, Fıkıh Teori ve Uygulamasında Yargılama ve İnfazın Aleniliği, İstanbul 29 Mayıs Üniversitesi Sosyal Bilimler Enstitüsü, Yayımlanmamış Doktora Tezi, İstanbul, 2020.

ABDURREZZAK, Ebû Bekr Abdurrezzâk b. Hemmâm es-San'ânî, el-Musannef (nşr. Habîburrahmân el-Azamî), I-XI, el-Mektebü'l-İ̀slâmî, Beyrut 1403/1982.

Aḥmed b. Ḥanbel, Ebû Abdullâh Aḥmed b. Muḥammed b. Ḥanbel eş-Şeybânî, el-Müsned (nşr. Şu 'ayb el-Arnavût, Âdil Murşid v.dğr), Muessesetu'r-Risâle, 1421/2001.

AHMED ZIYA, Mufassal Ameli ve Nazari Kanun-ı Ceza Teferruatı Şerhi, İstanbul, 1338.

AKGÜNDÜZ, Ahmed, Osmanlı Kanunnameleri ve Hukuki Tahlilleri, C.6, Fey Vakfi Yayınları, İstanbul, 1993.

AKGÜNDÜZ, Ahmed, Osmanlı Kanunnameleri ve Hukuki Tahlilleri, C.7, Fey Vakfi Yayınları, İstanbul, 1994.

AKGÜNDÜZ, Ahmed, Şeyhülislam Ebussuud Efendi Fetvaları (Fetava-yı Ebussuud Efendi), OSAV, İstanbul, 2018.

ARSLAN, Adem, İlk Devir İslam Ceza Hukukunda Had Cezalarının İnfazı, Harran Üniversitesi Sosyal Bilimler Enstitüsü, Yayımlanmamış Yüksek Lisans Tezi, Şanlıurfa, 2005.

AVCI, Mustafa, "Osmanlı İnfaz Hukukundaki Gelişmelere Genel Bir Bakış”, SÜHFD, Sy:3-4, 2004, (87-159).

AVCI, Mustafa, Osmanlı Ceza Hukuku Genel Hükümler (I), 3. Baskı, Adalet Yayınevi, Ankara, 2018.

AVCI, Mustafa, Osmanlı Ceza Hukuku Özel Hükümler (II), 3.Bask1, Adalet Yayınevi, Ankara, 2018.

AVCI, Mustafa, Hukuk Tarihimizde Hapis, 2. Baskı, Adalet Yayınevi, Ankara, 2019. 
AVCI, Mustafa / KARADAĞ, M. Mansur, İslam Hukukunda Kişilere Karşı Suçlar (Mi’yar-ı Adalet Şerhi), Adalet Yayınevi, Ankara, 2021.

BARKAN, Ömer Lütfi, XV ve XVI ıncı Asırlarda Osmanlı İmparatorluğunda Zirai Ekonominin Hukuki ve Mali Esasları Birinci Cilt Kanunlar, İstanbul, 1943.

BEHNESİ, Ahmed Fethi, el-Ukube fi fıkhi’l-İslami, Dirase Fıkhiyye Müteharrira, 2.Baskı, Kahire, 1961.

BEYHAKİ, Ebû Bekr Aḥmed b. el-Ḥuseyn, es-Sünenu'l-Kübrâ (nşr. Muhammed Abdulkadir Atâ), Beyrut 1424/2003.

BİLMEN, Ömer Nasuhi, Hukuk-ı İslâmiyye ve Istılahat-ı Fıkhiyye Kamusu, Bilmen Yayınevi, İstanbul, 1970.

BUHARİ, Ebû Abdillâh Muhammed b. İsmail, Sahih-i Buhari, terc. Mehmed Sofuoğlu, Ötüken Yayınları, İstanbul, 1990.

CİN, Halil / AKGÜNDÜZ, Ahmet, Türk Hukuk Tarihi, OSAV Yayınları, İstanbul, 2017.

DÂREKUTNÎ, Ebû'l-Hasen Alî b. Ömer el-Bağdâdî, Sünenü'd-Dârekutnî, I-V, Müessesetü'rRisâle, Beyrut 1424/2004.

DEVELLİĞLU, Ferit, Osmanlıca-Türkçe Ansiklopedik Lügat, Aydın Yayınları, Ankara, 2013.

EBU DAVUD, Süleyman b. Eş'as, Sünen-i Ebu Davud, terc. Abdullah Parlıyan, Konya Kitapç11ı, Konya, 2007.

EBU YUSUF, Yakub b. İbrahim, Kitabu'l-Harac, 2. Baskı, Özek Yayınları, (çev. A. Özek), İstanbul, 1973.

EBU ZEHRA, Muhammed, el-Cerime ve'l-Ukube fi Fıkhi'l-İslam, (İslam Hukukunda Suç ve Ceza), (çev. İ. Tüfekçi), İstanbul, 1994.

FENDOĞLU, Hasan Tahsin, Türk Hukuk Tarihi, Filiz Kitabevi, İstanbul, 2000.

FETAVA-YI ALİ EFENDİ, Açıklamalı Osmanlı Fetvaları, haz. H. Necati Demirtaş, Kubbealtı Neşriyat, İstanbul, 2014.

FETAVA-YI HİNDIYYE, Fetava-yı Alemgiriyye, (çev. M. Efe), Huzur Yayınları, İstanbul, 2004.

GÖKCEN, Ahmet, Tanzimat Dönemi Osmanlı Ceza Kanunları ve Bu Kanunlardaki Ceza Müeyyideleri, İstanbul, 1989.

HALEBİ, İbrahim, İzahı Mülteka el-Ebhur Tercümesi, (çev. M. Uysal), Dizerkonca Matbaası, İstanbul, 1968.

İBN ABİDIN, Muhammed Emîn, Reddü'l-Muhtar Ale'd-Dürri'l-Muhtar, (çev. A. Davudoğlu ve M. Savaş), Şamil Yayınları, İstanbul, 1983. 
İBN KAYYIM, el-Cevziyye, Şemseddin Ebu Abdullah Muhammed b. Ebu Bekr, İ'lamü'l Muvakkı'in, (çev. P. Düzenli), Pınar Yayınları, İstanbul, 2017.

İBN KUDAME, Ebu Muhammed Abdullah b. Ahmed b. Muhammed, el-Muğni Muhtasarı, Kısaltan ve yayına hazırlayan Hamed b. Abdülaziz el-Hammad, (çev. A. A. Tunçer), Karınca-Polen Yayınları, İstanbul, 2015.

İBN MACE, Muhammed b. Yezid Ebu Abdillah el-Kazvini, Sünen-i İbn Mace, çev. Haydar Hatipoğlu, Kahraman Yayınları, İstanbul, 1982.

İBN RÜŞD, Ebü'l-Velîd Muhammed b. Ahmed b. Muhammed el-Kurtubî, Bidâyetü’l-Müctehid ve Nihâyetü'l-Muktesid, (çev. A. Meylani, Redaksiyon ve Düzenleme: V. Akyüz), Ensar Neşriyat, İstanbul, 2015.

İNCE, İrfan, "Ridde", DİA, C.35, İstanbul, 2008.

KARAMAN, Hayreddin, İslam Hukukunda İctihad, 3. Baskı, DİB Yayınları, Ankara, 1985.

KÖROĞLU, Mehmet, İslam Ceza Hukukunda Ölüm Cezası ve İnfaz Usulleri, Atatürk Üniversitesi Sosyal Bilimler Enstitüsü, Yayımlanmamış Doktora Tezi, Erzurum, 2004.

Kur’an Yolu Türkçe Meal ve Tefsir, DİB Yayınları, Ankara, 2012.

MERĞİNANİ, Burhanüddin Ali b. Ebu Bekr, el-Hidaye, (Delilleriyle Hanefi Fıkhı), (çev. A. Meylani), Kahraman Neşriyat, İstanbul, ty.

MEZURİ, Waadi Süleyman, "Cezanın Ertelenmesi Beşeri Kanun ve İslam Hukuku Arasında Bir Mukayese", (çev. O. Güman), İslam Ceza Hukuku Uluslararası Sempozyumu Tebliğler Kitabı, Lale Yayıncılık, İstanbul, 2017, Cilt 2, (862-907).

MUTTAKÎ EL-HINDDî, Alâeddîn Alî b. Ḥisâmi'd-Dîn b. Kâdî Hân el-Kâdirî eş-Şâzelî el-Hindî el-Burhânfûrî, Kenzu'l- 'Ummâl (nşr. Bekrî Hayyânî), Müessesetü'r-Risâle, 1401/1981.

MÜSLIM, Ebü'l-Hüseyn Müslim b. el-Haccâc b. Müslim el-Kuşeyrî, Sahih-i Müslim, terc. Ahmed Davudoğlu, Sönmez Neşriyat, İstanbul, 1977.

ÖZBEK, Veli Özer, İnfaz Hukuku, 13.Bask1, Seçkin Yayınları, Ankara, 2021.

ÖZÇELİK, Selahittin, “Osmanlı İç Hukukunda Zorunlu Bir Tehir (Mürted Maddesi)”, OTAM Ankara Üniversitesi Osmanlı Tarihi Araştırma ve Uygulama Merkezi Dergisi, C.11, Sy:11, 2000, (347-438).

ÖZEN, Şükrü, “İnfaz”, DİA, C.22, İstanbul, 2000.

ÖZGENÇ, İzzet / ŞAHIN, Cumhur, İnfaz Hukuku, 3.Baskı, Seçkin Yayınları, Ankara, 2020.

ÖZGÜR, Mustafa, İslam İnfaz Hukuku, Cinius Yayınları, İstanbul, 2020.

SAĞLAM, M. Yılmaz, “İnfaz ve İnfaz Hukuku Kavramları Üzerine Bir İnceleme”, TBB Dergisi, 1995/4, (578-591). 
SAMİ, Mirat-ı Kanun-ı Ceza (Kanun-ı Ceza Şerhi), 2.Baskı, Dersaadet, 1324.

SERAHSİ, Ebu Sehl Ebu Bekir Muhammed b. Ahmed, Mebsût, ed. Mustafa Cevat Akşit, Gümüşev Yayıncılık, İstanbul, 2008.

ŞíRBİNİ, Şemseddin Muhammed b. Ahmed el-Hatîb, Muğni'l- Muhtac, (çev. S. Duman), Mirac Yayınları, İstanbul, 2017.

TALU, Mehmet, “Ebu Mihcen”, DİA, İstanbul, 1994.

UDEH, Abdülkadir, Mukayeseli İslam Ceza Hukuku, (çev. A. Şafak), Kayıhan Yayınları, 2. Bask1, İstanbul, 2012.

YILMAZ, Ejder, Hukuk Sözlüğü, 9.Bask1, Yetkin Yayınları, Ankara, 2005.

YURTSEVEN, Yılmaz, Klasik Dönem Osmanlı Ceza Hukukunda Tazir Suç ve Cezaları, Selçuk Üniversitesi Sosyal Bilimler Enstitüsü, Basılmamış Yüksek Lisans Tezi, Konya, 2001.

ZEYLAİ, Ebû Muhammed Abdullâh b. Yûsuf, Nasbu'r-Râye li Eḥâdîsi'l-Hidâye me'a Hâşiyetihî Buğyeti'l-Elme'î fî̀ Taḩrîci'z-Zeylaî (nşr. Muhammed Avvâme), I-IV, Müessesetü'r-Reyyân Beyrut, Dâru'l-Kible li's-Sekâfeti'l-İslâmiyye, Cidde 1418/1997.

ZUHAYLİ, Vehbe, İslam Fıkhı Ansiklopedisi, (ilmi müşavir M. Emin Saraç, çev. Heyet), Risale Yayınları, İstanbul, 1994.

\section{Kadı sicilleri}

Konya Kadı Sicilleri Defter 45, haz. İzzet Sak, Cemal Çetin, Konya, 2016.

İstanbul Kadı Sicilleri 7 - Üsküdar Mahkemesi 26 Numaralı Sicil (H. 970-971 / M. 15621563). / Rifat Günalan; Arapça metin Mehmet Akman ; kontrol eden Fikret Sarıcaoğlu ; proje yönetmeni M. Akif Aydın ; ed. Coşkun Yılmaz. -- İstanbul : Türkiye Diyanet Vakfi İslâm Araştırmaları Merkezi (İSAM), 2010.

İstanbul Kadı Sicilleri 14 - Rumeli sadareti Mahkemesi 56 Numaralı Sicil (H. 1042-1043/M. 1633). / Fuat Recep, Sabri Atay ; Arapça metin Mehmet Akman ; kontrol eden Fikret Sarıcaoğlu ; proje yönetmeni M. Akif Aydın ; ed. Coşkun Yılmaz. -- İstanbul : Türkiye Diyanet Vakfı İslâm Araştırmaları Merkezi (İSAM), 2011.

İstanbul Kadı Sicilleri 73 - Bab Mahkemesi 197 Numaralı Sicil (H. 1162-1163 / M. 17491750) / proje yönetmeni M. Âkif Aydın ; editör Coşkun Yılmaz; çeviri yazı / mukabele Nedim Pakırdağ - Abdullah Sivridağ ; kontrol M. Akif Aydın - Mehmet Akman - Feridun M. Emecen - İdris Bostan - Mehmet İpşirli. - İstanbul : Kültür AŞ, 2019.

İstanbul Kadı Sicilleri 69 - Bab Mahkemesi 172 Numaralı Sicil (H. 1152-1153 / M. 1740) / proje yönetmeni M. Âkif Aydın ; editör Coşkun Yılmaz ; çeviri yazı / mukabele Sabri Atay - Salih Kahriman ; kontrol M. Akif Aydın - Mehmet Akman - Feridun M. Emecen - İdris Bostan - Mehmet İpşirli. - İstanbul : Kültür AŞ, 2019. 
İstanbul Kadı Sicilleri 70 - Üsküdar Mahkemesi 403 Numaralı Sicil (H. 1154-1155 / M. 17401742) / proje yönetmeni M. Akif Aydın ; editör Coşkun Yılmaz; çeviri yazı / mukabele Mustafa Yılmaz v.dğr. ; kontrol M. Akif Aydın - Mehmet Akman - Feridun M. Emecen İdris Bostan - Mehmet İpşirli. - İstanbul : Kültür AŞ, 2019.

İstanbul Kadı Sicilleri 72 - Eyüp Mahkemesi 182 Numaralı Sicil (H. 1154-1161 / M. 17411748) / proje yönetmeni M. Âkif Aydın; editör Coşkun Yılmaz; çeviri yazı / mukabele Abdulkadir Altın - Salih Kahriman ; kontrol M. Akif Aydın - Mehmet Akman - Feridun M. Emecen - İdris Bostan - Mehmet İpşirli. - İstanbul : Kültür AŞ, 2019.

\section{Arşiv Belgeleri}

3 Numaralı Mühimme Defteri, Divan-1 Hümayun Sicilleri Dizisi:I, Ankara, 1993.

Başkanlık Osmanlı Arşivi, Ali Emiri Mustafa III. (AE.SMST.III), 49/3565. H-29-12-1173.

Başkanlık Osmanlı Arşivi, Ali Emiri Selim III (AE.SSLM.III), 189/11392. H-29-12-1207.

Başkanlık Osmanlı Arşivi, Bab-ı Asafi Divan-ı Hümayun Sicilleri Mühimme Defterleri, (A.DVNS.MHM.d), 127/907. H-30-09-1130.

Başkanlık Osmanlı Arşivi, Dahiliye Nezareti Mektubi Kalemi (DH.MKT), 2527/107.H-1705-1319.

Başkanlık Osmanlı Arşivi, Dahiliye Nezareti Mektubi Kalemi (DH.MKT), 352/16. H-12-091312.

Başkanlık Osmanlı Arşivi, Hatt-ı Hümayun (HAT), 339/19419. H-19-12-1237.

Başkanlık Osmanlı Arşivi, Hatt-ı Hümayun (HAT), 494/24280. H-03-05-1231.

Başkanlık Osmanlı Arşivi, İrade Hususi (İ.HUS), 168/72. H-22-06-1326.

Başkanlık Osmanlı Arşivi, Mabeyn-İrâde (MB.İ), 40/29. H-18-09-1294.

Başkanlık Osmanlı Arşivi, Sadaret Mektubi Kalemi Meclis-i Vala Evrakı (A.MKT.MVL), 145/35. H-24-10-1278.

Başkanlık Osmanlı Arşivi, Sadaret Mektubi Mühimme Kalemi Evrakı (A.MKT.MHM), 226/13. H-07-01-1278.

Başkanlık Osmanlı Arşivi, Sadaret Mektubi Mühimme Kalemi Evrakı (A.MKT.MHM), 617/9. H-20-04-1314. 